\title{
Nigerian Oil and Gas Industry Content Development Act's Perceived Performance Impact
}

\author{
Olakunle Thomas Ayoola \\ Walden University
}

\begin{abstract}
Petroleum-producing companies in Nigeria were forced to increase spending on Nigeriansourced materials and services from $\$ 8$ billion to $\$ 13$ billion since 2010 , due to the Nigerian Oil and Gas Industry Content Development Act that was implemented in 2010 to support local firms and improve the companies' performance. There is sparse research on how the act affected the companies' performance. This descriptive correlational study addressed the gap in the literature. Survey data from 372 employees of the five major petroleum-producing companies in Nigeria was analyzed. The study results indicated that the act had a positive effect on the employees' internal competence factor and the organizations' operational performance factor. The results are significant in understanding the impact of the act on performance.
\end{abstract}

Keywords: Nigerian Oil and Gas Industry Content Development Act, local content, perceived performance, employee performance, organizational performance, petroleum-producing companies

\section{Introduction}

The implementation of the Nigerian Oil and Gas Industry Content Development Act of 2010 has led to the spending of at least $70 \%$ of the average annual expenditure of over $\$ 18$ billion by the petroleum-producing companies in Nigeria on Nigerian-sourced materials and services (Chevron, 2012, 2014; Shell, 2013, 2015). Average annual local spending has increased to $\$ 13$ billion since 2010 in comparison to an average annual local spending of $\$ 8$ billion before 2010 (ExxonMobil 2015; Shell, 2013 , 2015). The increased annual spending on locally procured materials and services is a result of a change in government policy to boost local participation in the petroleum industry and improve the organizational performance of the petroleum-producing companies (Atsegbua, 2012; Ovadia, 2013).

Prior to the implementation of the act, the Nigerian petroleum industry was heavily dependent on materials and services mostly procured from foreign companies specializing in petroleum industry technology and services (Atsegbua, 2012). The dependence of the local oil and gas industry on externally sourced materials and services, and the resultant loss of income from the Nigerian economy to other countries, was a major concern to the government of Nigeria (Atsegbua, 2012; Ovadia, 2013). Furthermore, the Nigerian government was concerned about the lack of local capacity development in the area of technology development and provision of services to support the petroleum industry (Atsegbua, 2012). Based on these concerns, the government established the act and set up the Nigerian Content Monitoring Board to establish the regulatory framework of the act and monitor the implementation and compliance of the petroleum-producing companies (Atsegbua, 2012). 
The increase in local spending made it necessary to assess whether the companies have received commensurate returns on their investments through improved employee and organizational performance. In this study, I assessed the underresearched impact of the act on employees' task performance and organizational business performance in the petroleum-producing companies in Nigeria. The study's conclusions are useful to the government and managers of petroleum-producing companies in understanding the effects of the act on the employees' task performance and organizational business performance, and in understanding the pros and cons of the act in its current form. The study's outcomes have potential implications for positive social change through the identification of better local content policy implementation strategies to improve indigenous participation in the local petroleum industry and wealth redistribution in the Nigerian society.

\section{Problem Statement}

The petroleum-producing companies in Nigeria have been forced to increase their annual local spending by $63 \%$ since the implementation of the Nigerian Oil and Gas Industry Content Development Act in 2010 (Atsegbua, 2012; Ovadia, 2013). The increase in spending from $\$ 8$ billion in 2010 to $\$ 13$ billion in 2015 was due to the regulatory requirement to patronize Nigerian-sourced materials and services (Atsegbua, 2012; Nwapi, 2015). The general management problem was that despite substantial spending by the petroleum-producing companies on local content development, there is limited research on the effects of the act on the companies' performance. The specific management problem was to determine the impact of the act on employee and organizational performance in the major petroleum-producing companies in Nigeria. I addressed the specific management problem by carrying out a quantitative correlational study.

\section{Purpose of the Study}

The purpose of this descriptive correlational study was to examine the relationship between employees' perceived level of implementation of the Nigerian Oil and Gas Industry Content Development Act, employees' perceived task performance, and perceived organizational business performance in the five major petroleum-producing companies in Nigeria: (a) Shell, (b) ExxonMobil, (c) Chevron, (d) Total, and (e) Eni. The specific population group of this study was full-time employees of the five major petroleum-producing companies in Nigeria. I used a survey for data collection. The study results add to the body of knowledge on the effect of policy implementation in the Nigerian petroleum industry.

\section{Theoretical Foundation}

The theoretical foundation for this study was Bandura's (1989) social cognitive theory of human development. The theory links the influence of social interactions, personal experiences, and the environment to the behavior of an individual. Personality type influences the individual's ways of learning while the peculiar social practices or prevailing societal norms influence the individual's cultivated behavior (Bandura, 1989, p. 2). Personal or cognitive, environmental, and behavioral factors influence each other in a reciprocal and bidirectional manner to determine human behavior (Bandura, 1989, p. 2).

Personal qualities, social belief systems, and skill-oriented self-development affect the behavior of an individual (Bandura, 1989, p. 2). Similarly, the individual's behavior has an effect on the personal, behavioral, and environmental aspects of the individual's society (Bandura, 1989, p. 2). In summary, social cognitive theory posits that personal factors influence behavioral factors and vice versa. 
Likewise, behavioral factors influence environmental factors and vice versa, and environmental factors influence personal factors and vice versa. These three interactions shape overall human behavior and development; one factor does not necessarily have more influence on individual behavior than any other factor in any bidirectional pair (Bandura, 1989, pp. 2-3).

The aim of this quantitative study was to examine employees' perceived task performance and perceived organizational business performance in the petroleum-producing companies in Nigeria due to the implementation of a government policy that changed the work environment. Social cognitive theory was, therefore, a suitable theoretical basis on which to ground the study and address the research questions because the theory links the effects of a change in the environment to changes in human behavior and development. In a related application, social cognitive theory was applied to evaluate employees' response to performance appraisal (Miller, Verbos, \& Goswami, 2014).

\section{Definition of Terms}

The definitions of key terms and phrases used in the context of this study are as follows:

Employee's perceived task performance: A measure of the ability of an employee to carry out assigned tasks toward achieving organizational business objectives regarding performance factors that include the employee's knowledge of the task, adaptability, cooperation, quality of work done, quantity of work done, problem solving, decision making, leadership, professional attitude, integrity, versatility, and motivation (Ahmed, Sultana, Paul, \& Azeem, 2013; Cullen, Edwards, Casper, \& Gue, 2014; Katamba \& Salman, 2014).

Local content development: The development and use of local human and materials resources to supply goods and services to an industry (Monday, 2015; Ovadia, 2013).

Nigerian Oil and Gas Industry Content Development Act: The act implemented in 2010 to encourage local content development (Atsegbua, 2012).

Perceived organizational business performance: A measure of the degree to which an organization has performed relative to predetermined business objectives based on the employees' perception of performance metrics such as the efficiency of work processes, cost performance, competitiveness, profitability, growth, and customer satisfaction (Akça, Esen, \& Özer, 2013; Bulak \& Turkyilmaz, 2014; Hyoung \& Byoung, 2014).

Social cognitive theory: A theory in which personal, behavioral, and environmental factors influence the behavior of an individual (Bandura, 1989).

\section{Literature Review}

\section{Historical Development and Success of Local Content Initiatives}

Various factors influence the development and level of success of local content initiatives in diverse uses across different countries in the global petroleum industry. The emergence of Norway as a global force in petroleum production is due largely to the successful implementation of a local content development policy that started in the 1970s. The people of Norway developed the capability to create highly effective and profitable petroleum-producing companies and an internationally competitive petroleum services industry (Ryggvik, 2015). 
In the 2000s, the Government of Brazil embarked on the development of a framework for a local content policy designed for implementation in the Brazilian petroleum industry from the context of a system of innovation (Mendonça \& de Oliveira, 2013). The Government of Brazil used the Norwegian local content policy as a reference to compare and contrast the Brazilian local content policy (Mendonça \& de Oliveira, 2013). Several stakeholders were important in the successful implementation of the local content development initiative. The stakeholders include the national oil company, the subsidiaries of the national oil company, the legal sector, the regulatory agencies, and the government (Mendonça \& de Oliveira, 2013).

In Africa, the Government of Nigeria implemented the Nigerian Oil and Gas Industry Content Development Act in 2010 to boost local participation in the oil and gas industry (Atsegbua, 2012). The major stakeholders involved in the implementation of the act were multinational companies, indigenous companies, educational and research institutions, the Nigerian legal system, financial institutions, regulatory agencies, and the government (Atsegbua, 2012; Monday, 2015). The effective management of the roles and interrelationships of the stakeholders was crucial to achieving the country's local content development objectives, especially regarding the assurance of clear legal and industrial regulatory guidelines, and the provision of adequate funding to support the business of indigenous firms (Monday, 2015). It was also important to ensure knowledge transfer from multinational companies to indigenous firms to support the development of the local technical capacity for the petroleum industry (Monday, 2015).

Also in Africa, the Government of Ghana passed a local content law in 2013. The aim of the law was to encourage and improve the development of internal and external connections between Ghana's petroleum industry and the broader national economy (Arthur \& Arthur, 2014). Ghana's Ministry of Energy set up a project to enhance the capacity of indigenous Ghanaian firms and promote their participation in the petroleum industry. The project was funded with the assistance of the international oil companies (IOCs) who do business in the Ghanaian petroleum industry (Arthur \& Arthur, 2014).

\section{The Nigerian Oil and Gas Industry Content Development Act Implementation}

Nigeria is one of the world's top 10 biggest oil-exporting countries, and the local oil industry contributes $80 \%$ and $95 \%$ of Nigeria's revenues and foreign exchange, respectively (Atsegbua, 2012). The oil and gas deposit in the oil-rich Niger Delta region of the country has been the mainstay of the Nigerian economy and a major source of crude oil to meet part of the global demand for energy over several decades (Atsegbua, 2012). The Nigerian petroleum industry is also a means of creating jobs for the people (Abdulkabir, Sidique, Rahman, \& Hook, 2015). Consequently, the Nigerian government sought greater control of the country's most valuable natural resource as well as redistribution of the wealth accruing from the exploitation of oil and gas reserves in the country through the implementation of the Nigerian Oil and Gas Industry Content Development Act in 2010 (Nwapi, 2015; Ovadia, 2013).

\section{Impact of the Act}

The IOCs are developing and implementing effective corporate social responsibility (CSR) initiatives in support of the objectives of the Nigerian Oil and Gas Industry Content Development Act (Ngoasong, 2014). CSR involves the IOCs providing financial aid to local firms and investing in technical skills training to support technological capacity development in the host communities of the petroleum-producing companies in Nigeria (Ngoasong, 2014). The development of effective CSR 
initiatives will ensure the social and infrastructural development of Nigerian communities, especially the host communities of the petroleum-producing companies in the Niger Delta region of the country (Ngoasong, 2014; Renouard \& Lado, 2012). Cultural and socioeconomic inequalities and imbalances are the major reasons for the insecurity and violence in the Niger Delta region (Renouard $\&$ Lado, 2012). The IOCs need to do more than just pay corporate tax. The IOCs need to participate directly in the development of their host communities to address the problem of social and economic inequality (Renouard \& Lado, 2012).

The IOCs contributed to the achievement of the objectives of the Nigerian Oil and Gas Industry Content Development Act through workforce development, host community investments, supplier capacity development, research and development, stakeholder engagement, local technological capacity building, and preferential selection of local contractors for project execution (Monday, 2015; Ngoasong, 2014). The domiciliation of economic activities in the petroleum industry of Nigeria is a sustainable model for retaining control of the most valuable natural resource in the hands of the indigenous people (Ovadia, 2013). Improving the interactions among the most important stakeholders in the Nigerian petroleum industry beyond the unidirectional interaction between the government and the IOCs will also support the realization of the objectives of the act (Monday, 2015).

\section{Gap in the Literature}

A major gap in the literature is the absence of scholarly research on the impact of the Nigerian Oil and Gas Industry Content Development Act on employee and organizational performance in the Nigerian petroleum industry. Specifically, the impact of the employees' perception of the level of implementation of the act on employees' perceived task performance and perceived organizational

business performance in the petroleum-producing companies in Nigeria. Such a study is important to the IOCs because of their huge annual financial commitment to meeting the requirements of the act since 2010 (ExxonMobil 2015; Shell, 2013, 2015). The study is also useful to Nigerian government officials in improving policy development and implementation processes in the local petroleum industry. I addressed the identified gap in the literature in this study.

\section{Research Questions and Hypotheses}

To assess the correlation between employees' perception of the level of implementation of the Nigerian Oil and Gas Industry Content Development Act, employees' perceived task performance, and employees' perception of organizational business performance in the petroleum-producing companies in Nigeria, the research questions and hypotheses raised were the following:

Research Question 1: What is the relationship between the respondents' perception of the level of implementation of the act and their perceived task performance?

Hypothesis 10: There is not a significant relationship between the respondents' perception of the level of implementation of the act and their perceived task performance.

Hypothesis $1_{a}$ : There is a significant relationship between the respondents' perception of the level of implementation of the act and their perceived task performance. 
Research Question 2: What is the relationship between the respondents' perception of the level of implementation of the act and their perceived organizational business performance?

Hypothesis 20: There is not a significant relationship between the respondents' perception of the level of implementation of the act and their perceived organizational business performance.

Hypothesis $2 a$ : There is a significant relationship between the respondents' perception of the level of implementation of the act and their perceived organizational business performance.

\section{Methodology}

In this study, I used a quantitative research design and descriptive correlational method. The quantitative method is consistent with the aim of examining the correlation between two or more variables through data measurement, analysis, and comparison (Leedy \& Ormrod, 2010, p. 182). The independent variable was employees' perception of the level of implementation of the Nigerian Oil and Gas Industry Content Development Act. The dependent variables were employees' perceived task performance and perceived organizational business performance among the sample of petroleum-producing companies in Nigeria since the implementation of the act in 2010 .

\section{Population and Sampling}

I drew the primary sample from full-time employees of the five major petroleum-producing companies in Nigeria: (a) Shell, (b) ExxonMobil, (c) Chevron, (d) Total, and (e) Eni. The target population of full-time employees of the five major petroleum-producing companies in Nigeria consisted of about 12,000 employees, based on the corporate reports of the companies as of December 2015. The roles of the employees included entry-level workers, experienced technical and business professionals, and management roles.

The sampling strategy I employed in this study was purposive sampling, a form of nonprobabilistic sampling. Nonprobabilistic sampling involves the selection of components from a predetermined population group without any consideration for the randomness of selection of the components (Leedy \& Ormrod, 2010, p. 211). Purposive sampling involves the selection of people or units for a particular purpose because the particular people or units selected are representative of the wider group (Leedy \& Ormrod, 2010, p. 212).

The sampling strategy was appropriate for the study because the study was specific to the petroleum-producing companies in the Nigerian petroleum industry. I purposively selected the participants from among full-time employees of the five major petroleum-producing companies, who are part of a wider group of workers in the Nigerian petroleum industry. The calculated sample size for the study based on power analysis was 372 employees of the five major petroleum-producing companies in Nigeria (Rea \& Parker, 2014, p. 169).

\section{Data Collection and Analysis}

I received approval to conduct the research study from Walden University's Institutional Review Board (Approval Number: 09-19-16-0298710). I used a survey instrument to gather quantitative data on the subjective opinions of employees of the selected petroleum-producing companies. A survey is suitable for a research study where it is difficult to directly observe and measure the required data, 
as was the case for this study (Balnaves \& Caputi, 2001, p. 75). I disseminated the online selfadministered survey through a link in an email to a sample population of 372 employees of the five major petroleum-producing companies in Nigeria.

I treated the Likert-scale data as interval data by anchoring only the extreme ends of the choices on the 5-point Likert scale with words so that the middle choices could be viewed as equal intervals between the extremes (Norman, 2010). I used the Pearson product-moment correlation to determine the correlation between employees' perceived level of implementation of the Nigerian Oil and Gas Industry Content Development Act, employees' perceived task performance, and perceived organizational business performance (Leedy \& Ormrod, 2010, p. 273). In addition to the correlation analysis, I used the exploratory factor analysis to identify the most interrelated variables or underlying factors that supported the impact of the act on employees' perceived task performance and perceived organizational business performance (Leedy \& Ormrod, 2010, p. 282; Norman, 2010).

\section{Validity and Reliability}

I conducted a pilot study with a sample size of 20 employees of Shell Nigeria to test the internal consistency and reliability of the survey instrument regarding the consistency of the responses from the participants in the study to the survey questions. I conducted the Cronbach's coefficient of alpha test on the responses from the pilot study to test the internal consistency and reliability of the survey instrument. The first set of responses was related to the questions on the respondents' perception of the level of implementation of the Nigerian Oil and Gas Industry Content Development Act and its impact on their perceived task performance. The Cronbach's coefficient of alpha for the first set of questions was 0.91 . The second set of responses was related to the questions on the respondents' perception of the level of implementation of the Nigerian Oil and Gas Industry Content Development Act and its impact on their perceived organizational business performance. The Cronbach's coefficient of alpha for the second set of questions was 0.83 .

The results of the statistical analysis showed that the Cronbach's coefficient of alpha is greater than 0.70 for the two sets of questions addressing the dependent variables. I used the results to confirm the internal consistency and reliability of the survey instrument in its current form for application in the main study (Raggi et al., 2014; Silva, Taveira, Marques, \& Gouveia, 2015; Tavakol \& Dennick, 2011; Villeneuve et al., 2015). The outcomes of the pilot study also confirmed the sufficiency of the survey instrument to address the research questions.

\section{Results}

\section{Descriptive Statistics}

About half (49\%) of the 372 respondents in the main study were within the age range of 31-40 years old. Thirty-one percent of the respondents were within the age range of 41-50 years old. Eleven percent of the respondents were within the age range of $18-30$ years old, while $9 \%$ of the respondents were over 50 years old. Furthermore, 245 of the respondents (66\%) and 127 of the respondents (34\%) were male and female, respectively. The data on the level of education of the respondents showed that $54 \%$ of the respondents had a bachelor's degree, while $41 \%$ had a master's degree. Four percent of the respondents had an advanced graduate study or doctorate degree, while only $1 \%$ had a polytechnic/technical college qualification. The majority of the respondents (63\%) were technical professionals, while $17 \%$ were in management roles in their current place of employment. Fourteen percent of the respondents were business professionals, while $6 \%$ were entry level employees. On the 
number of years of work experience of the respondents, $32 \%$ of the respondents had 10-15 years of work experience, while $24 \%$ had 5-10 years of work experience. Twenty percent of the respondents had 15-20 years of work experience, while $15 \%$ had over 20 years of work experience. Nine percent of the respondents had $0-5$ years of work experience.

On the respondents' perception of how well the current place of employment has met the requirements of the Nigerian Oil and Gas Industry Content Development Act since its implementation in 2010, $57 \%$ of the respondents reported a high level of compliance, while $34 \%$ of the respondents reported a very high level of compliance. Eight percent of the respondents reported an average level of compliance, while $1 \%$ of the respondents reported a low level of compliance. Among the predominant $67 \%$ of respondents with over 10 years of work experience, $95 \%$ of them reported their perception of how well their current place of employment has met the requirements of the act since its implementation in 2010 as either a high or a very high level of compliance. Also, among the main group of $63 \%$ technical professionals, $91 \%$ of them reported their perception of how well their current place of employment has met the requirements of the act since its implementation in 2010 as either a high or a very high level of compliance. The reported perception of a high or a very high level of compliance among the largest groups of respondents indicated a clear understanding of the act and its implementation in the Nigerian petroleum industry.

\section{Inferential Statistics}

I used the Pearson product-moment correlation to determine the correlation between employees' perceived level of implementation of the Nigerian Oil and Gas Industry Content Development Act, employees' perceived task performance, and perceived organizational business performance (Leedy \& Ormrod, 2010, p. 273). In addition to the correlation analysis, I used the exploratory factor analysis to identify the most interrelated variables or underlying factors that supported the impact of the act on employees' perceived task performance, and perceived organizational business performance (Leedy \& Ormrod, 2010, p. 282; Norman, 2010).

\section{First Research Question and Hypotheses}

I computed a new combined variable by aggregating the scores of the first set of responses on the respondents' perception of the level of implementation of the Nigerian Oil and Gas Industry Content Development Act and its impact on their perceived task performance. I computed a Pearson productmoment correlation coefficient to assess the relationship between the respondents' perception of the level of implementation of the act and their perceived task performance. There was a positive correlation between the two variables, $r=0.403, n=372, p=0.01$, which was statistically significant. The result showed that a high level of perceived compliance with the requirements of the act correlated with a high level of perceived task performance. Based on the outcome of the Pearson product-moment correlation, I rejected the null hypothesis for the first research question.

\section{Second Research Question and Hypotheses}

I computed a new combined variable by aggregating the scores of the second set of responses on the respondents' perception of the level of implementation of the Nigerian Oil and Gas Industry Content Development Act and its impact on their perceived organizational business performance. I computed a Pearson product-moment correlation coefficient to assess the relationship between the respondents' perception of the level of implementation of the act and their perceived organizational business performance. There was a positive correlation between the two variables, $r=0.244, n=372$, $p=0.01$, which was statistically significant. The result showed that a high level of perceived compliance with the requirements of the act correlated with a high level of perceived organizational 
business performance. Based on the outcome of the Pearson product-moment correlation, I rejected the null hypothesis for the second research question.

I also computed a Pearson product-moment correlation coefficient to assess the relationship between the respondents' perceived task performance and their perceived organizational business

performance. There was a positive correlation between the two variables, $r=0.574, n=372, p=0.01$, which was statistically significant. The result showed that a high level of perceived task performance correlated with a high level of perceived organizational business performance. Table 1 shows the results of the computation of the Pearson product-moment correlation coefficients for the new combined dependent variables.

Table 1. Pearson Product-Moment Correlation Coefficients Between the Independent and the Dependent Variables of the Main Study

\begin{tabular}{lccc}
\hline & $\begin{array}{c}\text { Perception of the } \\
\text { Level of } \\
\text { Implementation of } \\
\text { the Act }\end{array}$ & $\begin{array}{c}\text { Perceived Task } \\
\text { Performance }\end{array}$ & $\begin{array}{c}\text { Perceived } \\
\text { Organizational } \\
\text { Business } \\
\text { Performance }\end{array}$ \\
\hline $\begin{array}{l}\text { Perception of the level of } \\
\text { implementation of the act }\end{array}$ & 1.000 & $0.403^{* *}$ & $0.244^{* *}$ \\
$\begin{array}{l}\text { Perceived task performance } \\
\begin{array}{l}\text { Perceived organizational } \\
\text { business performance }\end{array}\end{array}$ & $0.403^{* *}$ & 1.000 & $0.574^{* *}$ \\
\hline
\end{tabular}

** Statistically significant $(p=0.01)$.

Additionally, I computed the Pearson product-moment correlation coefficients to assess the relationship between the respondents' perception of the level of implementation of the Nigerian Oil and Gas Industry Content Development Act and their responses to each question related to their perceived task performance. The outcomes were positive correlations between the respondents' perception of the level of implementation of the act and their perceived knowledge of the tasks, adaptability to the new way of working, cooperation with contractors/stakeholders, quality of work performed, problem-solving skills, decision-making skills, leadership skills, professional attitude, integrity, versatility, and motivation, which were statistically significant. The outcomes supported the rejection of the null hypothesis for the first research question.

I also computed the Pearson product-moment correlation coefficients to assess the relationship between the respondents' perception of the level of implementation of the Nigerian Oil and Gas Industry Content Development Act and their responses to each question related to their perceived organizational business performance. The outcomes were positive correlations between the respondents' perception of the level of implementation of the act and their perceived efficiency of work processes, competitiveness, profitability, growth, and customer satisfaction, which were statistically significant. The outcomes supported the rejection of the null hypothesis for the second research question. Table 2 shows the results of the computation of the Pearson product-moment correlation coefficients for the subvariables of the dependent variables. 
Table 2. Pearson Product-Moment Correlation Coefficients Between the Independent Variable and the Subvariables of the Dependent Variables of the Main Study

\begin{tabular}{lc}
\hline Variable & $\begin{array}{c}\text { Perception of the Level of } \\
\text { Implementation of the Act }\end{array}$ \\
\hline Perceived task performance & $0.294^{* *}$ \\
Knowledge of the tasks performed & $0.432^{* *}$ \\
Adaptability to the new way of working & $0.462^{* *}$ \\
Cooperation with contractors/stakeholders & $0.135^{* *}$ \\
Quality of work performed & 0.093 \\
Quantity of work performed & $0.387^{* *}$ \\
Problem-solving skills & $0.337^{* *}$ \\
Decision-making skills & $0.232^{* *}$ \\
Leadership skills & $0.207^{* *}$ \\
Professional attitude & $0.312^{* *}$ \\
Integrity & $0.358^{* *}$ \\
Versatility & $0.167^{* *}$ \\
Motivation & \\
Perceived organizational business performance & $0.110^{*}$ \\
Efficiency of work processes & -0.066 \\
Cost performance & $0.114^{*}$ \\
Competitiveness & $0.189^{* *}$ \\
Profitability & $0.252^{* *}$ \\
Growth & $0.422^{* *}$ \\
Customer satisfaction &
\end{tabular}

* Statistically significant $(p=0.05) .{ }^{* *}$ Statistically significant $(p=0.01)$.

\section{Exploratory Factor Analysis}

I conducted the exploratory factor analysis of the survey responses to identify groups of highly interconnected subvariables within the two dependent variables. I grouped these highly interconnected subvariables as the major underlying themes or factors. I used the Kaiser-MeyerOlkin measure of sampling adequacy, Bartlett's test of sphericity, and the scree plot to identify the major factors within the dependent variables. I also used the principal axis factoring method of extraction and the varimax with Kaiser normalization rotation method to compute the factor matrix and the rotated factor matrix for each major factor. The four major underlying factors that emerged from the exploratory factor analysis follow.

\section{Internal competence factor}

The results of the exploratory factors analysis of the responses to the questions related to the respondents' perceived task performance indicated the interrelationship among six of the 12 subvariables. The six subvariables were the respondents' perceived (a) problem-solving skills, (b) decision-making skills, (c) versatility, (d) integrity, (e) adaptability, and (f) cooperation with contractors/stakeholders. I called this the internal competence factor because the six subvariables relate to the respondents' ability to reactively and internally improve their competence as a result of the impact of the Nigerian Oil and Gas Industry Content Development Act.

\section{External competence factor}

The results of the exploratory factors analysis of the responses to the questions related to the respondents' perceived task performance also indicated the interrelationship among another five of the 12 subvariables. The five subvariables were the respondents' perceived (a) work quality, (b) leadership skills, (c) motivation, (d) professional attitude, and (e) work quantity. I called this the 
external competence factor because the five subvariables relate to the respondents' ability to proactively and externally demonstrate the improvements in their competence as a result of the impact of the Nigerian Oil and Gas Industry Content Development Act.

\section{Operational performance factor}

The results of the exploratory factors analysis of the responses to the questions related to the respondents' perceived organizational business performance indicated the interrelationship among four of the six subvariables. The four subvariables were the respondents' perceived (a) customer satisfaction, (b) growth, (c) competitiveness, and (d) the efficiency of work processes. I called this the operational performance factor because the four subvariables relate to the organization's operational performance as a result of the impact of the Nigerian Oil and Gas Industry Content Development Act.

\section{Financial performance factor}

The results of the exploratory factors analysis of the responses to the questions related to the respondents' perceived organizational business performance also indicated the interrelationship between the other two of the six subvariables. The two subvariables were the respondents' perceived (a) cost performance and (b) profitability. I called this the financial performance factor because the two subvariables relate to the organization's financial performance as a result of the impact of the Nigerian Oil and Gas Industry Content Development Act.

The outcomes of the exploratory factor analysis indicated that the respondents' perception of the level of implementation of the Nigerian Oil and Gas Industry Content Development Act had a stronger impact on the internal competence factor and the operational performance factor. The major underlying themes or factors that I identified supported the correlation between the independent and the dependent variables. Table 3 shows a summary of the exploratory factor analysis of the responses from the respondents in the main study. 
Table 3. Exploratory Factor Analysis of the Dependent Variables of the Main Study

\begin{tabular}{|c|c|c|c|}
\hline \multirow[b]{2}{*}{ Variable } & \multicolumn{2}{|c|}{ Rotated Factor Loading } & \multirow[b]{2}{*}{ Factor Name } \\
\hline & Factor 1 & Factor 2 & \\
\hline \multicolumn{4}{|l|}{ Perceived task performance } \\
\hline Problem-solving skills & 0.840 & & Internal competence \\
\hline Decision-making skills & 0.835 & & \\
\hline Versatility & 0.828 & & \\
\hline Integrity & 0.793 & & \\
\hline Adaptability & 0.791 & & \\
\hline $\begin{array}{l}\text { Cooperation with } \\
\text { contractors/stakeholders }\end{array}$ & 0.708 & & \\
\hline Quality of work performed & & 0.706 & External competence \\
\hline Leadership skills & & 0.661 & \\
\hline Motivation & & 0.608 & \\
\hline Professional attitude & & 0.602 & \\
\hline $\begin{array}{l}\text { Quantity of work } \\
\text { performed }\end{array}$ & & 0.544 & \\
\hline \multicolumn{4}{|l|}{$\begin{array}{l}\text { Perceived organizational } \\
\text { business performance }\end{array}$} \\
\hline Customer satisfaction & 0.718 & & Operational performance \\
\hline Growth & 0.689 & & \\
\hline Competitiveness & 0.633 & & \\
\hline $\begin{array}{l}\text { Efficiency of work } \\
\text { processes }\end{array}$ & 0.466 & & \\
\hline Cost performance & & 0.913 & Financial performance \\
\hline Profitability & & 0.460 & \\
\hline
\end{tabular}

\section{Discussion}

\section{Contribution to the Body of Knowledge in the Research Literature}

\section{First Research Question}

The Pearson product-moment correlation coefficient indicated a statistically significant, positive correlation $(r=0.403)$ between the respondents' perception of the level of implementation of the Nigerian Oil and Gas Industry Content Development Act and their perceived task performance (Table 1). Consequently, I rejected the null hypothesis for the first research question. The result also showed that a high level of perceived compliance with the requirements of the act correlated with a high level of perceived task performance (Table 2). More specifically, the outcome of the exploratory factor analysis of the dependent variable revealed that the Nigerian Oil and Gas Industry Content Development Act had the most impact on the internal competence factor, which comprised the respondents' perceived problem-solving skills, decision-making skills, versatility, integrity, adaptability, and cooperation with contractors/stakeholders (Table 3). The results of the statistical analysis indicated that the respondents adapted to the new way of working as a result of the act. The respondents also saw improvements in their ability to solve diverse work-related problems and make appropriate decisions, as well as improvements in their integrity and cooperation with contractors/stakeholders. To a lesser extent, the results showed that the respondents saw improvements in their leadership skills, motivation, professional attitude, quality of work performed, and quantity of work performed. 
The indicated improvement in the internal competence factor of the respondents in the main study is of significance to managers of the five major petroleum-producing companies in Nigeria. Managers should leverage the act to develop the ability of their employees in the aspects of problem-solving skills, decision-making skills, versatility, integrity, adaptability, and cooperation with contractors/stakeholders. The improvement of the employees' ability in these aspects would benefit the organizations in terms of improved employee productivity and interpersonal relationships in the workplace.

\section{Second Research Question}

The Pearson product-moment correlation coefficient indicated a statistically significant, positive correlation $(r=0.244)$ between the respondents' perception of the level of implementation of the Nigerian Oil and Gas Industry Content Development Act and their perceived organizational business performance (Table 1). Consequently, I rejected the null hypothesis for the second research question. The result also showed that a high level of perceived compliance with the requirements of the act correlated with a high level of perceived organizational business performance (Table 2). More specifically, the outcome of the exploratory factor analysis of the dependent variable revealed that the Nigerian Oil and Gas Industry Content Development Act had the most impact on the operational performance factor, which comprised the respondents' perceived customer satisfaction, growth, competitiveness, and efficiency of work processes at their current place of work (Table 3). The results of the statistical analysis indicated that the respondents saw improvements in the customer satisfaction level of the contractors/stakeholders that they interacted with in the course of their work. The results also indicated that the respondents saw improvements in the growth, market competitiveness, and efficiency of work processes at their current place of work. To a lesser extent, the results showed that the respondents saw a slight improvement in the profitability of their current place of work. The respondents also saw a worsening of the cost performance at their current place of work as a result of the act.

The indicated improvement in the operational performance factor of the respondents in the main study is of significance to managers of the five major petroleum-producing companies in Nigeria and the policy makers of the Nigerian government. Managers and the policy makers of the Nigerian government should leverage the act to improve the business interactions between the employees of the petroleum-producing companies and the employees of the indigenous firms seeking to do business with the petroleum-producing companies. Managers and the policy makers of the Nigerian government should encourage the development of the ability of the employees of the petroleumproducing companies and the indigenous firms in the aspects of contractor/stakeholder satisfaction and the efficiency of work processes. The improvement of the employees' ability in these aspects would benefit the organizations in terms of improved interpersonal relationships and better business interactions between contractors and the petroleum-producing companies. The improved business interactions would help the policy makers of the Nigerian government to achieve the aim of the act to boost local participation in the Nigerian petroleum industry.

The study outcomes also indicated a worsening of the cost performance of the five major petroleumproducing companies in Nigeria since the implementation of the Nigerian Oil and Gas Industry Content Development Act. Managers of the five major petroleum-producing companies in Nigeria should carry out a meticulous examination of their spending on Nigerian-sourced goods and services. The comprehensive examination of the spending patterns of the five major petroleum-producing companies in Nigeria could show areas for potential cost performance improvements in the procurement of Nigerian-sourced goods and services. 
Additionally, the Pearson product-moment correlation coefficient indicated a statistically significant, positive correlation $(r=0.574)$ between the respondents' perceived task performance and their perceived organizational business performance (Table 1). The result indicated that improvements in employee performance translate to improvements in organizational performance. Managers of the five major petroleum-producing companies in Nigeria should create the enabling environments to encourage improvements in employee task performance. Improvements in employee task performance would improve organizational performance and ensure business success (Cullen et al., 2014; Dar, Bashir, Ghazanfar, \& Abrar, 2014; Devonish, 2013; Suliman \& Harethi, 2013).

\section{Contribution to the Application of Social Cognitive Theory}

The outcomes of the exploratory factor analysis of the dependent variable of perceived task performance indicated that the Nigerian Oil and Gas Industry Content Development Act had a significant impact on the internal competence factor, which comprised the respondents' perceived problem-solving skills, decision-making skills, versatility, integrity, adaptability, and cooperation with contractors/stakeholders (Table 3). The results indicated that the respondents adapted to the new way of working as a result of the act. The respondents improved their ability to solve diverse work-related problems and make appropriate decisions. The respondents also improved their integrity and cooperation with the contractors/stakeholders. The outcomes indicated that the change in the business environment affected the behavior of the employees as a response to the change, and established the applicability of social cognitive theory to this study.

\section{Recommendations}

\section{Theoretical Recommendation for Future Research}

The focus of future research studies could be a more detailed and intensive study of the impact of the Nigerian Oil and Gas Industry Content Development Act on personal qualities and professional competence of a few randomly selected employees within the Nigerian petroleum industry. The appropriate framework for such a study is the ecological model of human development (Bronfenbrenner, 1979). Human development is an evolving relation between the environment, the individual, and the interaction brought about by the individual's perception of the environment (Bronfenbrenner, 1979, p. 3). An intensive study over a longer period could reveal a more subtle impact of the act on personal qualities and professional competence.

\section{Methodological Recommendation for Future Research}

Another possible area of focus for future research studies is the examination of the impact of the Nigerian Oil and Gas Industry Content Development Act on contracting and procurement of Nigerian-sourced goods and services in one of the major petroleum-producing companies in Nigeria. Such a study would enable managers of the selected petroleum-producing company to better understand the direct impact of the act on the cost performance of the company. The study would enable managers of the selected petroleum-producing company to identify areas for possible cost performance improvement in the contracting and procurement process of the company. The study could also be a qualitative research design and case study methodology (Balnaves \& Caputi, 2001, pp. 66-67; Leedy \& Ormrod, 2010, p. 108; Miles, Huberman, \& Saldana, 2014, pp. 28-30). 


\section{Practical Recommendations for Future Research}

Furthermore, a possible area of focus for future research studies is the examination of the impact of the Nigerian Oil and Gas Industry Content Development Act on the wider Nigerian petroleum industry. This study was restricted in scope to the five major petroleum-producing companies in Nigeria. The focus of future research studies could be the examination of the impact of the act on employee and organizational performance of the other sectors of the petroleum industry such as the petroleum services sector, the midstream petroleum transportation, storage, and marketing sector, and the downstream petroleum refining and processing sector.

\section{Implications for Positive Social Change}

The implications of this study for positive social change in Nigeria covered the aspects of policy design and implementation, and societal development. The study outcomes have potential implications for positive social change through the identification of better local content policy design and implementation strategies to improve the indigenous participation and wealth redistribution in the Nigerian society. The study outcomes indicated that the Nigerian Oil and Gas Industry Content Development Act had a major impact on the internal competence factor of the respondents which comprised the problem-solving skills, decision-making skills, versatility, integrity, adaptability, and cooperation with contractors/stakeholders. In the future, the policy makers for the Nigerian government should focus on improvements to the design and implementation strategies of the policy to enhance the internal competence of employees and other stakeholders in the petroleum industry, especially the aspect of cooperation with contractors that is important to the success of the act.

The achievement of an enabling environment to boost local participation in the petroleum industry depends on the cooperation between managers and employees of the petroleum-producing companies and the local firms seeking to do business with the petroleum-producing companies. Achieving the creation of businesses through improved cooperation and the efficiency of work processes between the petroleum-producing companies and the local firms has the potential to stimulate economic growth in the host communities of the petroleum-producing companies. Economic growth can be achieved through employment generation, increased commercial activities, and the advancement of local technological capacity development. This could contribute to wealth redistribution in the Nigerian society and help in achieving the aim of the Nigerian Oil and Gas Industry Content Development Act.

\section{Conclusions}

In this study, I have examined the impact of employees' perception of the level of implementation of the Nigerian Oil and Gas Industry Content Development Act on their perceived task performance and perceived organizational business performance in the five major petroleum-producing companies in Nigeria: (a) Shell, (b) ExxonMobil, (c) Chevron, (d) Total, and (e) Eni. This study was necessary because there was a gap in the research literature on the impact of the act on employee and organizational performance in the Nigerian petroleum industry. The general management problem was that despite substantial spending by the petroleum-producing companies on local content development, there is limited research on the effects of the act on the companies' performance. The specific management problem was to determine the impact of the act on employee and organizational performance in the major petroleum-producing companies in Nigeria.

The study results showed that the Nigerian Oil and Gas Industry Content Development Act had improved employees' internal competence factor and organizations' operational performance factor. The study outcomes indicated that managers need to empower employees to perform at a high level 
of competence to effectively contribute to organizational performance. The study outcomes showed an opportunity for the policy makers of the Nigerian government and managers of the petroleumproducing companies to use the indicated improvements in the operational performance factor to improve indigenous participation and develop the local technological capacity for the Nigerian petroleum industry. The study outcomes have potential implications for positive social change through better local content policy design and implementation in the Nigerian petroleum industry to unlock the benefits of the Nigerian Oil and Gas Industry Content Development Act to the technological and socioeconomic development of Nigeria. Researchers could focus on a comprehensive examination of the impact of the Nigerian Oil and Gas Industry Content Development Act on employees' internal competence factor in future studies.

\section{References}

Abdulkabir, A. N., Sidique, S. F., Rahman, A. A., \& Hook, L. S. (2015). Relationship among local content policy, indigenous oil firms' participation and job creation in Nigeria: A theoretical concept. Journal of Developing Areas, 49, 425-437.

Ahmed, I., Sultana, I., Paul, S. K., \& Azeem, A. (2013). Employee performance evaluation: A fuzzy approach. International Journal of Productivity and Performance Management, 62, 718-734. doi:10.1108/IJPPM-01-2013-001

Akça, Y., Esen, S., \& Özer, G. (2013). The effects of education on enterprise resource planning implementation success and perceived organizational performance. International Business Research, 6, 168-179. doi:10.5539/ibr.v6n5p168

Arthur, P., \& Arthur, E. (2014). Local content and private sector participation in Ghana's oil industry: An economic and strategic imperative. Africa Today, 61, 56-77.

Atsegbua, L. A. (2012). The Nigerian Oil and Gas Industry Content Development Act 2010: An examination of its regulatory framework. OPEC Energy Review, 36, 479-494. doi:10.1111/j.1753-0237.2012.00225.x

Balnaves, M., \& Caputi, P. (2001). Introduction to quantitative research methods: An investigative approach. Los Angeles, CA: Sage.

Bandura, A. (1989). Social cognitive theory. In R. Vasta (Ed.), Annals of child development: Six theories of child development (Vol. 6, pp. 1-85). Greenwich, CT: JAI Press.

Bronfenbrenner, U. (1979). The ecology of human development. Cambridge, MA: Harvard University Press.

Bulak, M. E., \& Turkyilmaz, A. (2014). Performance assessment of manufacturing SMEs: A frontier approach. Industrial Management \& Data Systems, 114, 797-816. doi:10.1108/IMDS-112013-0475

Chevron. (2012). 2012 Corporate responsibility report: Chevron in Nigeria. Retrieved from http://www.chevron.com/documents/pdf/2012_NigeriaCR_Report.pdf

Chevron. (2014). 2014 Corporate responsibility report highlights. Retrieved from http://www.chevron.com/documents/pdf/corporateresponsibility/Chevron_CR_Report_2014.pdf

Cullen, K. L., Edwards, B. D., Casper, W. C., \& Gue, K. R. (2014). Employees' adaptability and perceptions of change-related uncertainty: Implications for perceived organizational support, job satisfaction, and performance. Journal of Business and Psychology, 29, 269-280. doi:10.1007/s10869-013-9312-y 
Dar, A. T., Bashir, M., Ghazanfar, F., \& Abrar, M. (2014). Mediating role of employee motivation in relationship to post-selection HRM practices and organizational performance. International Review of Management and Marketing, 4, 224-238. Retrieved from http://www.econjournals.com/index.php/irmm

Devonish, D. (2013). Workplace bullying, employee performance and behaviors. Employee Relations, 35, 630-647. doi:10.1108/ER-01-2013-0004

ExxonMobil. (2015). Capacity development initiatives: National content. Retrieved from http://corporate.exxonmobil.com/en/company/worldwideoperations/locations/nigeria/community/development-initiatives

Hyoung, K. M., \& Byoung, K. C. (2014). How an organization's ethical climate contributes to customer satisfaction and financial performance. European Journal of Innovation Management, 17, 85-106. doi:10.1108/EJIM-03-2013-0020

Katamba, A. S., \& Salman, A. A. (2014). An assessment of the levels of job motivation and satisfaction as predictors of job performance of library personnel in Nigerian universities. Journal of Balkan Libraries Union, 2, 26-33. doi:10.16918/bluj.3477

Leedy, P. D., \& Ormrod, J. E. (2010). Practical research: Planning and design (9th ed.). Boston, MA: Pearson.

Mendonça, R. W., \& de Oliveira, L. G. (2013). Local content policy in the Brazilian oil and gas sectoral system of innovation. Latin American Business Review, 14, 271-287. doi:10.1080/10978526.2013.833477

Miles, M. B., Huberman, M. A., \& Saldana, J. (2014). Qualitative data analysis (3rd ed.). Thousand Oaks, CA: Sage.

Miller, J. S., Verbos, A. K., \& Goswami, A. (2014). Employee social cognition and performance evaluation process reactions. Personnel Review, 43, 515-535. doi:10.1108/PR-01-2011-0011

Monday, J. U. (2015). Local content policy, human capital development and sustainable business performance in the Nigerian oil and gas industry. Journal of Management and Sustainability, 5, 75-83. doi:10.5539/jms.v5n1p75

Ngoasong, M. Z. (2014). How international oil and gas companies respond to local content policies in petroleum-producing developing countries: A narrative enquiry. Energy Policy, 73, 471-479. doi:10.1016/j.enpol.2014.05.048

Norman, G. (2010). Likert scales, levels of measurement and the "laws" of statistics. Advances in Health Sciences Education, 15, 625-632. doi:10.1007/s10459-010-9222-y

Nwapi, C. (2015). Defining the "local" in local content requirements in the oil and gas and mining sectors in developing countries. Law and Development Review, 8, 187-216. doi:10.1515/ldr2015-0008

Ovadia, J. S. (2013). The Nigerian "one percent" and the management of national oil wealth through Nigerian content. Science \& Society, 77, 315-341. doi:10.1521/siso.2013.77.3.315

Raggi, A., Giovannetti, A. M., Schiavolin, S., Leonardi, M., Bussone, G., Grazzi, L., . . D'Amico, D. (2014). Validating the migraine-specific quality of life questionnaire v2.1 (MSQ) in Italian inpatients with chronic migraine with a history of medication overuse. Quality of Life Research, 23, 1273-1277. doi:10.1007/s11136-013-0556-9 
Rea, L. M., \& Parker, R. A. (2014). Designing and conducting survey research. San Francisco, CA: Jossey-Bass.

Renouard, C., \& Lado, H. (2012). CSR and inequality in the Niger Delta (Nigeria). Corporate Governance, 12, 472-484. doi:10.1108/14720701211267810

Ryggvik, H. (2015). A short history of the Norwegian oil industry: From protected national champions to internationally competitive multinationals. Business History Review, 89, 3-41. doi:10.1017/S0007680515000045

Shell. (2013). Nigeria's local content marathon: Key strides, forward steps and challenges. Retrieved from https://s04.static-shell.com/content/dam/shellnew/local/country/nga/downloads/pdf/speeches/iw-speech-local-content.pdf

Shell. (2015). Shell at a glance: Shell in Nigeria. Retrieved from http://www.shell.com.ng/aboutshell/at-a-glance.html

Silva, A. D., Taveira, M. D. C., Marques, C., \& Gouveia, V. V. (2015). Satisfaction with life scale among adolescents and young adults in Portugal: Extending evidence of construct validity. Social Indicators Research, 120, 309-318. doi:10.1007/s11205-014-0587-9

Suliman, A., \& Harethi, B. A. (2013). Perceived work climate and employee performance in public security organizations in the UAE. Transforming Government: People, Process and Policy, 7, 410-424. doi:10.1108/TG-03-2012-0001

Tavakol, M., \& Dennick, R. (2011). Making sense of Cronbach's alpha. International Journal of Medical Education, 2, 53-55. doi:10.5116/ijme.4dfb.8dfd

Villeneuve, L., Trudel, G., Préville, M., Dargis, L., Boyer, R., \& Bégin, J. (2015). Dyadic Adjustment Scale: A validation study among older French-Canadians living in relationships. Canadian Journal on Aging, 34, 26-35. doi:10.1017/S0714980814000269

The International Journal of Applied Management and Technology (IJAMT), sponsored by Walden University's School of Management, is a peer-reviewed, online journal that addresses contemporary national and international issues related to management and technology. The objectives of the IJAMT are to: (a) encourage collaborative and multi-disciplinary examinations of important issues in business and technology management, and (B) engage scholars and scholar-practitioners in a dynamic and important dialogue.

Walden University Publishing: http://www.publishing.waldenu.edu 